\title{
EVALUASI PENGGUNAAN PROGRAM LIPI Mix DALAM MEMBUAT FORMULASI PREMIX MINERAL UNTUK PAKAN TERNAK
}

\author{
Hendra Herdian ${ }^{1}$
}

\section{INTISARI}

Telah dibuat suatu program worksheet oleh penulis untuk memformulasi premix mineral untuk pakan ternak yang dinamai LIPI Mix. Untuk mengetahui kemampuan program ini, maka dilakukan evaluasi penggunaan program. Evaluasi dilakukan melalui pemecahan masalah suatu contoh model pencampuran mineral untuk pakan ternak dari referensi yang ada dengan menggunakan program ini. Hasil yang diperoleh menunjukkan bahwa program ini mampu melakukan proses perhitungan untuk memformulasi suatu campuran/premix mineral untuk pakan ternak.

(Kata kunci: Premix mineral, Program LIPIMix).

Buletin Peternakan 29 (3): 122-130, 2005

\footnotetext{
' UPT BPPTK LIPI Desa Gading Kecamatan Playen Kabupaten Gunungkidul Yogyakarta.
} 


\title{
THE EVALUATION OF LIPI Mix PROGRAM ON FORMULATING FEED MINERAL PREMIX
}

\begin{abstract}
A LIPI Mix worksheet program was made by the authors to perform the feed minerals premix formulation calculation. The program was evaluated by conducting calculation to solve feed minerals formulation problem from an available reference. The Results showed that this program was able to be used for feed premix mineral formulation by producing similar result obtained from the reference calculation.
\end{abstract}

(Key words : Feed mineral premix, LIPIMix program).

\section{Pendahuluan}

Sebagai salah satu komponen dari bahan pakan, ketersediaan mineral baik mineral yang dibutuhkan dalam jumlah banyak (macro minerals) ataupun dalam jumlah yang sedikit (trace minerals) sangatlah penting adanya. Dalam beberapa kasus, penambahan (suplementasi) mineral-mineral ke dalam ransum pakan sangatlah dibutuhkan. Penambahan ini dimungkinkan apabila secara keseluruhan ransum pakan mengalami defisiensi terhadap sejumlah mineral akibat kualitas bahan pakan yang jelek atau karena memang mineralmineral tersebut kandungannya sedikit dan hanya terdapat pada lokasi-lokasi tertentu sehingga tanaman yang dijadikan bahan pakan tidak memiliki unsur mineral tersebut Khusus untuk ternak ruminansia, ketersediaan mineral yang cukup sangatlah dibutuhkan karena selain untuk membantu metabolisme ternak itu sendiri juga untuk membantu metabolisme mikroba dalam rumen (Cullison, 1978, Lasley, 1981).

Suplementasi mineral ke dalam pakan ternak memiliki berbagai macam cara. Salah satu diantaranya adalah dengan pembuatan suatu campuran awal mineral yang dikenal dengan istilah premix. Premix sendiri mengandung arti campuran dari berbagai bahan sumber vitamin (premix vitamin atau sumber mineral mikro (premix mineral) atau campuran kedua-duanya (premix vitamin-mineral) Kamal, M.,1998). Campuran mineral ini pada saatnya nanti dapat dicampur ulang (disuplementasikan) terhadap campuran pakan yang lain seperti pada konsentrat atau dicampurkan pada ransum lengkap.

Pada proses pembuatan premix mineral ini beberapa hal yang harus diperhatikan adalah: pengetahuan mengenai jenis bahan/senyawa yang dapat dipergunakan sebagai sumber mineral yang dapat dicerna dan tidak berbahaya bagi ternak itu sendiri, kandungan unsur mineral yang dikandung dalam bahan/senyawa sumber mineral, tingkat kebutuhan unsur mineral dalam campuran akhir pakan/ransum dan proses formulasi pencampuran semua bahan/senyawa sumber mineral menjadi satu (Jurgens, 1974). Untuk mempermudah proses-proses di atas, dibuatlah suatu program aplikasi dalam bentuk Worksheet Microsoft Excel ${ }^{\circ}$ yang mampu membantu penyelesaian sejumlah proses-proses di atas yang dinamai program worksheet LIPI Mix. Program ini bersifat bebas guna pakai Ifreeware dengan tujuan pengembangan agar dapat membantu semua pihak yang berkaitan dengan proses pembuatan premix mineral.

Program ini mampu memformulasikan hingga 18 jenis bahan/senyawa sumber mineral sekaligus. Untuk mengetahui kemampuan program ini secara keseluruhan, perlu dilakukan evaluasi yang lebih mendalam dari program ini dalam melakukan formulasi premix.

\section{Materi dan Metode}

\section{Materi}

Program yang dievaluasi adalah program LIPI Mix. Program ini dibuat pada tahun 2004 di UPT BPPTK LIPI Yogyakarta. 
Program aplikasi ini merupakan program lembar kerja (worksheet) Microsoftt Excel ${ }^{\circledR}$ yang telah diprogram untuk melakukan proses perhitungan pembuatan premix mineral untuk pakan ternak. Pemilihan program worksheet Microsoft Excel ini dilakukan karena program ini selain mudah diperoleh juga penggunaannya relatif lebih mudah. Program LIPI Mix terdiri dari program utama yang berisi program perhitungan premix mineral pakan ternak dan data base yang berisi berat molekul unsur-unsur (Rosenberg, 1980). Alur proses dari program ini dapat dilihat pada Gambar 1 .

Input : Sejumlah bahan/senyawa sumber mineral yang akan dipergunakan (Input : Some demical molecular compound will used as mineral sources)

Hitung : kandungan unsur mineral yang terdapat dalam bahan/senyawa sumber Calculate: The content ofmineral/atom as element of molecular compound

Input : unsur yang dikehendaki dan kandungan yang harus ada dalam suplemen/ransum pakan yang akan diberikan (Input : Mineral/atom will used as minerakource individually and also a level to be added on the supplement/ration)

Hitung : jumlah akhir bahan/senyawa sumber yang dibutuhkan lalu formulasikan dengan bahan/senyawa sumber yang lain (Calculate the quantity of molecular compound source that consist the element needed individually and then calculate the whole molecular compounds. together as mineral source compound)

Terakhir : tambahkan bahan pembawa/carrier dari premix sehingga jumlah total premix sesuai yang diinginkan (Finally : Add carrier feedstuff untilreach the appropriate weight of premix) 


\section{Metode}

Untuk menilai kemampuan dari program ini maka dilakukan evaluasi penggunaan program dalam melakukan proses perhitungan formulasi premix mineral. Evaluasi dilakukan dengan mengadaptasi contoh formulasi premix pakan ternak sapi potong dari Jurgens (1974) yang menggunakan sejumlah senyawa sebagai sumber mineralnya. Model formulasi ini kemudian dicoba dipecahkan dengan menggunakan program LIPI Mix. Hasil yang diperoleh dari perhitungan Program LIPI Mix kemudian dibandingkan dengan hasil perhitungan manual dari Jurgens, 1974 tersebut di atas. Evaluasi dilakukan untuk menilai sampai seberapa jauh program ini mampu menghasilkan formulasi yang sama dengan hasil yang diperoleh dari model referensi.

\section{Model formulasi premix mineral (Jurgens, 1974)}

Pada contoh ini, dicoba diformulasikan campuran trace mineral untuk sapi potong yang akan digunakan pada tingkat 10 pound/ton suplemen pakan sapi. Sebagai bahan pembawa/Carrier digunakan Ground limestone. Perhitungan dilakukan untuk mengetahui sampai seberapa banyak senyawa-senyawa itu dipergunakan dan berapa komposisi total akhir premix berikut jumlah Carrier untuk premix yang diperlukan. Adapun senyawa sumber yang digunakan dapat dilihat pada Tabel 1 .

\section{Perhitungan menurut program LIPIMix}

$\mathrm{Hal}$ pertama yang dilakukan untuk menyusun formula premix mineral dalam program ini adalah memasukkan senyawasenyawa sumber lengkap dengan rumus kimia senyawa tersebut ke dalam tabel sumber senyawa yang ada pada worksheet seperti pada Gambar 2. Sebetulnya pada program LIPI Mix ini dapat dimasukkan nama dari senyawasenyawa sumber sebagai keterangan dan harga per-kilogram senyawa tersebut. Adanya data harga senyawa ini memungkinkan, pada akhir perhitungan, kita dapat memperoleh harga akhir premix. Apabila kita telah memasukkan senyawa-senyawa sumber mineral tadi, secara otomatis pada tabel yang lain dalam worksheet LIPI Mix akan terisi oleh kandungan unsurunsur komponen senyawa tadi, hal ini dapat terlihat pada Gambar 3 .

Berikutnya dimasukkan ke dalam tabel yang lain dalam worksheet yang sama mengenai batasan level pemberian masing-masing unsur dalam ransum serta jumlah premix total dan jumlah bahan pakan yang akan disuplemen (berat premix dikonversikan dahulu ke dalam gram). Hal ini dijelaskan pada Gambar 4. Sebetulnya data lain yang dapat dimasukkan pada tabel ini adalah nama, harga Carrier, dan kadar kemurnian masing-masing senyawa (dalam kajian soal ini, dianggap kandungan semua senyawa adalah $100 \%$ ).

Tabel 1. Senyawa sumber mineral yang akan digunakan sebagai suplemen pakan sapi (Chemical molecular compounds used as cattle feed supplement)

\begin{tabular}{lcccc}
\hline $\begin{array}{c}\text { Senyawa } \\
\text { Molecular } \\
\text { compound) }\end{array}$ & $\begin{array}{c}\text { Berat atom } \\
\text { (Atomic } \\
\text { weight) }\end{array}$ & $\begin{array}{c}\text { Berat formula } \\
\text { (Formula } \\
\text { weight) }\end{array}$ & $\begin{array}{c}\text { \% elemen } \\
\text { (Element } \\
\text { content \%) }\end{array}$ & $\begin{array}{c}\text { Level Pemberian setiap } \\
\text { pound suplemen } \\
\text { (Level to be added per } \\
\text { pound supplement) }\end{array}$ \\
\hline MnSO4 & $54.94(\mathrm{Mn})$ & 151.00 & $36.38 \mathrm{Mn}$ & $15 \mathrm{mg}(\mathrm{Mn})$ \\
$\mathrm{CuSO} 4$ & $63.54(\mathrm{Cu})$ & 159.60 & $39.81 \mathrm{Cu}$ & $5 \mathrm{mg}(\mathrm{Cu})$ \\
$\mathrm{COSO} 4 \mathrm{H} 20$ & $58.93(\mathrm{Co})$ & 172.99 & $34.07 \mathrm{Co}$ & $0.5 \mathrm{mg}(\mathrm{Co})$ \\
FeSO4-7H2O & $55.85(\mathrm{Fe})$ & 277.91 & $20.10 \mathrm{Fe}$ & $15.0 \mathrm{mg}(\mathrm{Fe})$ \\
$\mathrm{ZnSO} 4-\mathrm{H} 2 \mathrm{O}$ & $65.37(\mathrm{Zn})$ & 179.43 & $36.43 \mathrm{Zn}$ & $5 \mathrm{mg}(\mathrm{Zn})$ \\
\hline
\end{tabular}




\section{LIPI $\left.\right|_{\max }$ u \\ FEED MURERAL PPEGIX PROGRAM \\ Design Oy, Hendra Herdion (Hendravtgyahoo cocn)}

\section{Indonesian institute or seience UPT BPPTK \\ Feed Program Unit}

$$
\text { =input Cell }
$$

Otherwise $=$ Flxed Cell

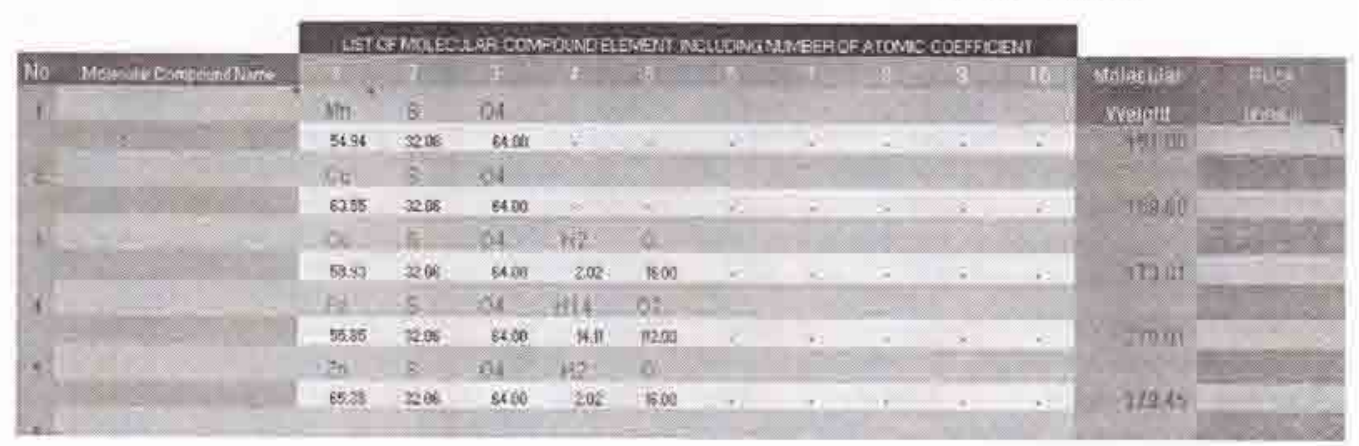

Gambar 2. Input senyawa-senyawa sumber mineral dalam LIPI Mix (Molecular compounds input on LIPI Mix).

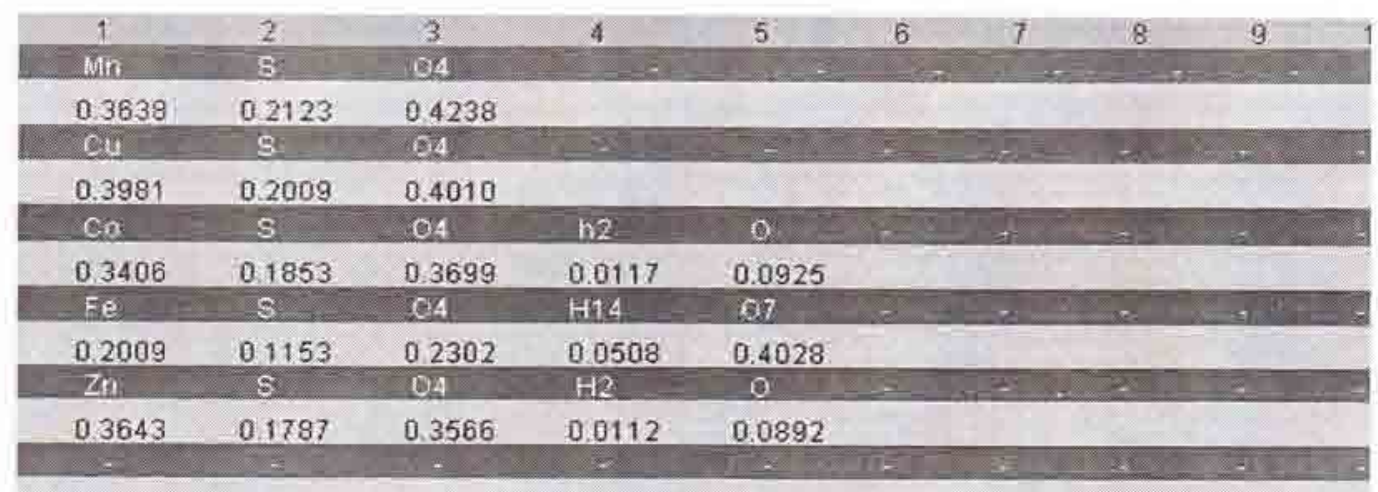

Gambar 3. Kandungan unsur untuk setiap senyawa sumber mineral (Minerallatomic content of molectilar compound mineral sources). 


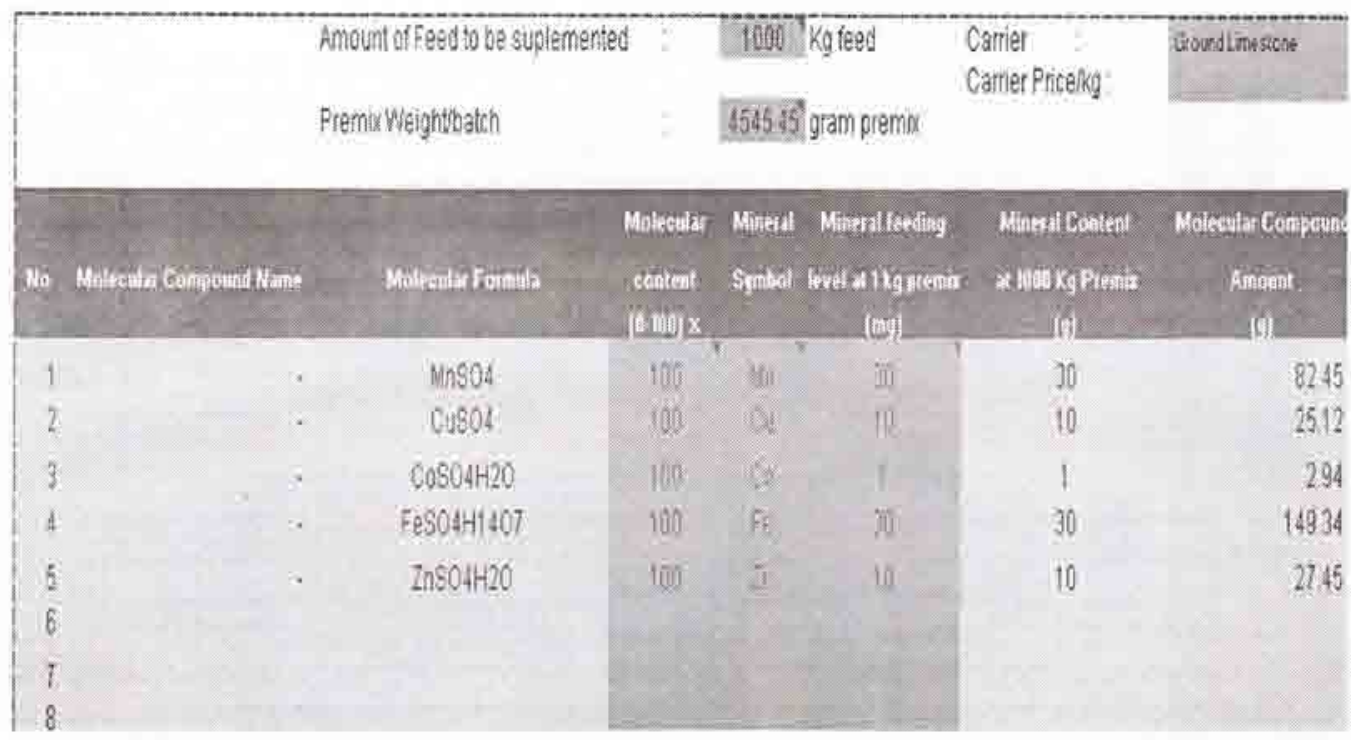

Gambar 4. Batasan-batasan level pemberian mineral (Feed mineral levels to be added)

Tabel 2. Formulasi akhir premix (Final premix formulation)

\begin{tabular}{|c|c|c|c|}
\hline \multirow{2}{*}{$\begin{array}{l}\text { Senyawa sumber } \\
\text { (Molecular } \\
\text { compound } \\
\text { sources) }\end{array}$} & \multicolumn{2}{|r|}{$\begin{array}{c}\text { Unsur } \\
\text { (Mineral/atom) }\end{array}$} & \multirow{2}{*}{$\begin{array}{l}\text { Jumlah senyawa sumber } \\
(\mathrm{g}) \text { (Quantity of } \\
\text { molecular compound } \\
\text { sources }(\mathrm{g}))\end{array}$} \\
\hline & $\begin{array}{l}\text { Lambang } \\
\text { (Symbols) }\end{array}$ & $\begin{array}{l}\text { Total jumlah yang dibutuhkan setiap } \\
\text { ton }(\mathrm{g}) \text { (Total mineral requirement } \\
\text { per ton }(\mathrm{g}))\end{array}$ & \\
\hline $\mathrm{MnSO} 4$ & $\mathrm{Mn}$ & 30 & 82,46 \\
\hline CuSO4 & $\mathrm{Cu}$ & 10 & 25,12 \\
\hline $\mathrm{CoSO} 4-\mathrm{H}_{2} \mathrm{O}$ & Co & 1 & 2,93 \\
\hline $\mathrm{FeSO} 4-7 \mathrm{H} 2 \mathrm{O}$ & $\mathrm{Fe}$ & 30 & 149,25 \\
\hline $\mathrm{ZnSO} 4-\mathrm{H} 2 \mathrm{O}$ & $\mathrm{Zn}$ & 10 & 27,45 \\
\hline \multicolumn{3}{|l|}{ Total } & 287,21 \\
\hline \multicolumn{3}{|c|}{ Sumber trace mineral (Trace mineral source quantity) (lbs) } & 0,63 \\
\hline \multicolumn{3}{|c|}{ Ground limestone (Carrier quantity) (lbs) } & 9,37 \\
\hline \multicolumn{3}{|c|}{ Total (Total quantitiy of finishing premix) (lbs) } & 10 \\
\hline
\end{tabular}

\section{Hasil dan Pembahasan}

Hasil akhir formulasi menurut Jurgens, 1974 seperti pada Tabel 2. Sedangkan program LIPI Mix menghasilkan perhitungan seperti pada Gambar 5 yang terlihat bahwa terdapat perbedaan pada jumlah akhir campuran senyawa sumber mineral, dimana dari perhitungan Jurgens (1974) memberikan nilai 287,21 g, sedangkan pada IIIPI Mix menghasilkan nilai $287,30 \mathrm{~g}$. Perbedaan ini disebabkan terdapatnya perbedaan perhitungan kandungan $\mathrm{Fe}$ dalam 
senyawa FeSO4-7H2O yaitu Jurgens menghitung senilai 0,2010 (Tabel 1) sedangkan kandungan Fe menurut program LIPI Mix adalah senilai 0,2009 (Gambar 3). Perhitungan kadar suatu unsur mineral dalam suatu senyawa diperlukan untuk menghitung jumlah senyawa sumber mineral tersebut. Jumlah senyawa sumber mineral berpengaruh terhadap komposisi akhir premix mengingat jumlah dan komposisi premix merupakan penjumlahan dari senyawasenyawa sumber mineral yang dibutuhkan pada kadar tertentu untuk ransum pakan ternak dan jumlah bahan pembawa/carrier (Kamal, M, 1998). Terdapatnya perbedaan perhitungan kandungan mineral $\mathrm{Fe}$ di atas dimungkinkan apabila terdapat perbedaan penafsiran berat atom untuk masing-masing unsur (LIPI Mix menggunakan sumber data berat atom dari Rosenberg, (1980)), tetapi apabila ditelaah lebih lanjut ternyata pada pembahasan yang lain pada referens yang sama Jurgens (1974) menyebutkan kandungan unsur $\mathrm{Fe}$ dalam senyawa FeSO4. 7H2O adalah sama dengan perhitungan LIPIMix yaitu sebesar 0,2009. Dengan adanya hal ini kesimpulan awal yang dapat diambil adalah kemungkinan telah terjadi inkonsistensi penulisan data pada perhitungan Jurgens (1974). Oleh karena itu untuk membuktikan kemampuan program secara lebih baik, maka dicoba dilakukan perhitungan ulang dengan memasukkan nilai kandungan Fe sebesar 0,2010 ke dalam program (dilakukan dengan memasukkan langsung nilai tersebut kepada tabel kandungan unsur dalam senyawa), dengan anggapan bahwa proses perhitungan oleh Jurgens (1974) sudah betul. Hasilnya terlihat pada Gambar 6.

Hasil dari Gambar 6 memperlihatkan hasil perhitungan campuran final premix sumber mineral sudah sama dengan perhitungan Jurgen $(287,21 \mathrm{~g}=0,63 \mathrm{lbs})$ sedangkan untuk berat Ground Limestone setelah dikonversi ulang ke pound menghasilkan nilai yang sama $(4258,25 \mathrm{~g}$ $=9,37 \mathrm{lbs}$ ), hal ini menunjukkan bahwa secara konsep perhitungan program ini sudah sesuai dengan konsep perhitungan Jurgens (1974) sehingga secara umum program ini disimpulkan dapat melakukan proses perhitungan untuk memformulasi premix mineral pakan ternak.

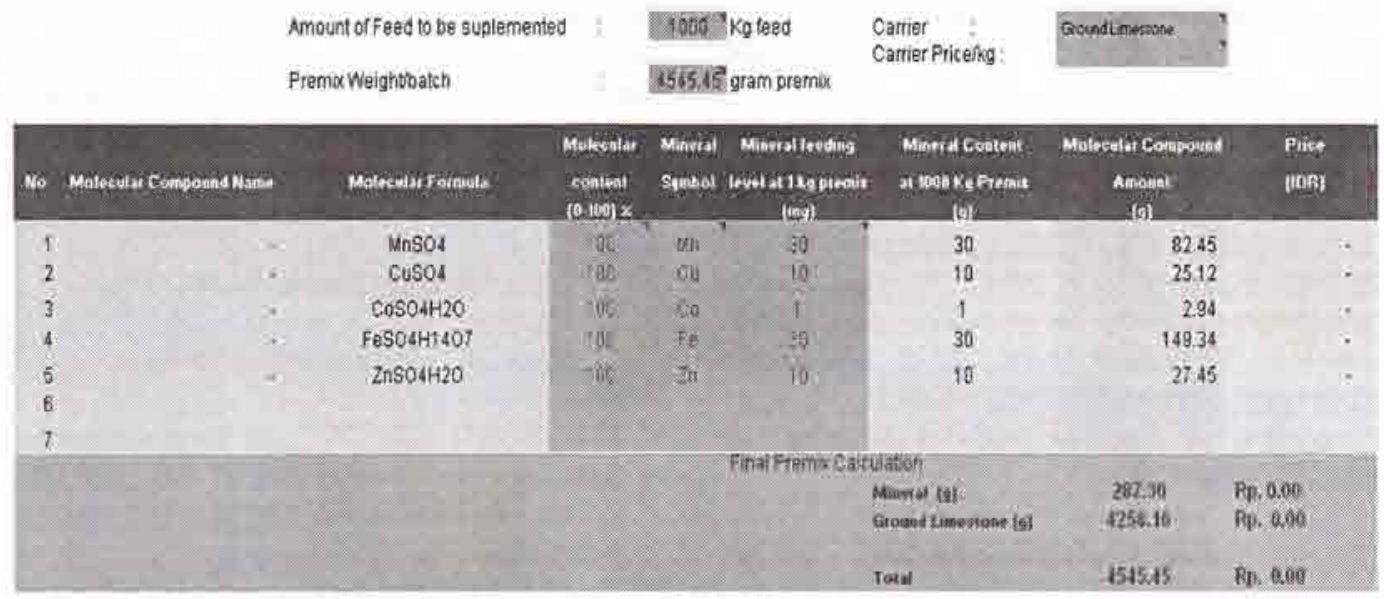

Gambar 5. Hasil akhir formulasi berdasarkan program LIPI Mix (LIPI Mix final formulation result). 


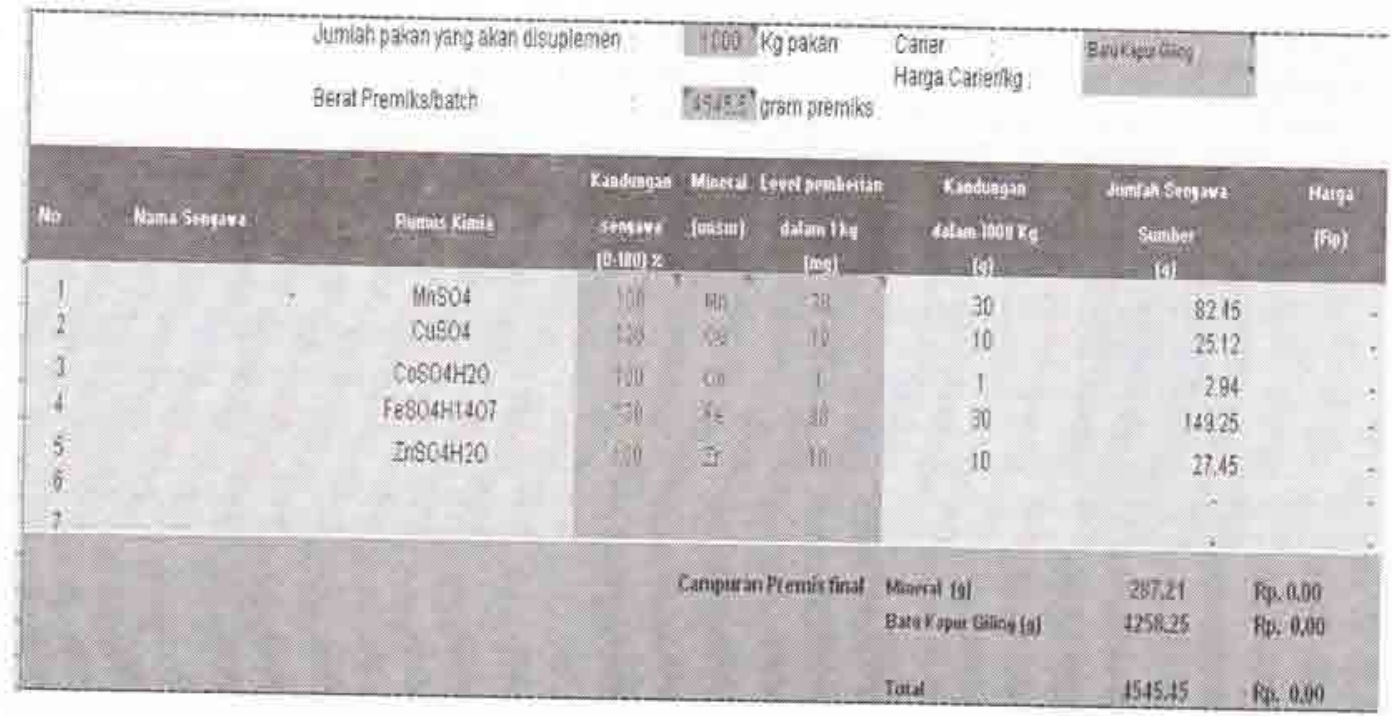

Gambar 6. Hasil kalkulasi ulang program LIPI Mix (LIPI Mix recalculation result).

Informasi yang diperoleh dari Gambar 6 . menunjukkan bahwa komposisi akhir dari premix adalah jumlah total senyawa-senyawa sumber mineral yaitu sebesar 287,21 g. $(0,63$ lbs), jumlah Ground Limestone sebagai Carrier adalah 4258,25 g. (9,37 lbs) sehingga jumlah total premix sebesar $4545,45 \mathrm{~g} .(10 \mathrm{lbs})$. Informasi harga premix dan nama-nama dari senyawa bahan tidak terlihat karena informasi tersebut tidak terdapat pada model yang dibuat oleh Jurgens,1974. Pada perhitungan praktis infromasi harga ini cukup herguna untuk menghitung berapa harga pokok dari premix tersebut. Worksheet tersebut di atas dapat langsung dicetak pada kertas dengan menggunakan fasilitas pencetakan yang ada pada Microsoft Excel ${ }^{\oplus}$.

\section{Kesimpulan dan Saran}

Secara umum program LIPI Mix dapat membantu proses perhitungan formulasi pencampuran bahan/senyawa sumber mineral untuk membuat premix mineral, perbedaan perhitungan dapat terjadi apabila terdapat penafsiran data berat atom/unsur yang berbeda antara data yang terdapat di dalam data base program dan data dari si pengguna program, untuk itu sebaiknya apabila diperlukan data base ini dapat di sesuaikan terlebih dahulu oleh sipengguna sebelum digunakan. Saran lainnya adalah periu adanya pengembangan kemampuan program untuk memformulasikan premix yang lain selain premix mineral.

\section{Ucapan Terima kasih} kepada :

Penulis mengucapkan terima kasih

1. Kantor UPT BPPTK LIPI Yogyakarta atas bantuan fasilitas hardware dan software dalam pembuatan program dan penyusunan tulisan ini.

2. Dr. Ir. Putut Irwan Pudjiono, Ka UPT BPPTK LIPI Yogyakarta atas saran-saran penulisan makalah ini.

3. Dr. Ir. Subiyatno, PUSINOV LIPI atas saransaran HAKI-nya. 


\section{Daftar Pustaka}

Cullison, A. E. 1979. Feed and Feeding Animal Nutrition. Prentice-Hall of India. India, pp. $81-84$

Jurgens, M. H.1974. Applied Animal Feeding and Nutrition $3^{\text {rd }} / \mathrm{ed}$, Kindall/hunt Publishing Company, Iowa, pp. 80-84.

Kamal, M. 1998. Bahan Pakan dan Ransum Ternak, Jurusan Nutrisi dan Makanan
Ternak, Fakultas Peternakan, Universitas Gadjah Mada. Yogyakarta, hal. 81-86

Lasley, J. F. 1981. Beef Cattle Production. Prentice-Hall, Inc. New Jersey, pp. 322324.

Rosenberg, J. L. 1980. Theory and Problems of College Chemistry 6/ed. Schaum's Outline Series. Singapore, p.313. 